\title{
Neurolathyrism in Vapniarka: Medical Heroism in a Concentration Camp
}

\author{
Jarred Garfinkle, Frederick Andermann, Michael I. Shevell
}

\begin{abstract}
Stories abound about the medical abuses that have come to define medicine and the "pseudo"-neurosciences in the Third Reich. Well known are the Nazi program of euthanasia and the neuroscientific publications that arose from it. Nevertheless, during this widespread perversion of medical practice and science, true medical heroics persisted, even in the concentration camps. In December 1942, inmates of Camp Vapniarka began experiencing painful lower extremity muscle cramps, spastic paraparesis, and urinary incontinence. In order to reduce the cost of feeding the 1200 , mostly Jewish, inmates of Camp Vapniarka and surreptitiously hasten their deaths, the Nazi-affiliated Romanian officers of the camp had begun feeding them a diet high in Lathyrus sativus. L. sativus is the neurotoxin implicated in neurolathyrism, a degenerative disease of the upper motor neurons. Dr. Arthur Kessler, one of the camp's prisoners, eventually identified the source of the epidemic. Armed with this knowledge, the inmates collectively organized to halt its spread.
\end{abstract}

RÉSUMÉ: Le neurolathyrisme à Vapniarka : héroïsme médical dans un camp de concentration. Il existe de nombreux récits d'abus médicaux que l'on considère maintenant comme ayant caractérisé la médecine et les "pseudo"-neurosciences sous le Troisième Reich. Le programme nazi d'euthanasie et les publications neuroscientifiques qui en découlèrent sont bien connus. Cependant, parallèlement à ce travestissement très répandu de la pratique médicale et de la science, de véritables actes d'héroïsme médical ont existé, même à l'intérieur des camps de concentration. En décembre 1942, les prisonniers du camp de Vapniarka ont commencé à présenter des crampes musculaires douloureuses aux membres inférieurs, une paraparésie spastique et de l'incontinence urinaire. Pour réduire le coût de la nourriture des 1200 prisonniers du camp de Vapniarka, surtout des Juifs, et hâter subrepticement leur décès, les officiers roumains complices des nazis avaient commencé à leur fournir une diète riche en Lathyrus sativus. Le L. sativus contient la neurotoxine qui cause le neurolathyrisme, une maladie dégénérative du neurone moteur supérieur. Le Dr Arthur Kessler, un des prisonniers du camp, a éventuellement identifié la source de l'épidémie. Fort de cette information, les prisonniers se sont organisés afin de mettre un terme à l'épidémie.

Can. J. Neurol. Sci. 2011; 38: 839-844

The most intense modern corruption of medicine's core values took place during the era of the Third Reich ${ }^{1}$. Respected physicians and sadistic poseurs took advantage of either the Nazi program of active euthanasia or the utter abrogation of human rights and dignity to advance their research ${ }^{2}$. Much has been written about the hideous and inhumane medical experimentation that occurred in Nazi Germany in both the concentration camps and the ivory tower, much of it in the "neurosciences"1,3. Less discussed are stories of medical triumph that also occurred during this era in the same setting. One such largely forgotten incident concerns neurolathyrism. It concerns a physician-inmate of Camp Vapniarka, which was located in Transnistria, Romania, who helped save hundreds of lives by identifying the cause of a paralyzing epidemic disease that afflicted the camp's inmates in the winter of 1943, and how he worked with fellow inmates in trying to curb its spread.

\section{Early History and Toxicology of Neurolathyrism}

Neurolathyrism is a neurologic condition that develops following the long-term ingestion of Lathyrus sativus, the grass pea, in high amounts. The early history of the disease has been reviewed by Bruyn and Poser $^{4}$. The first ever recorded lathyrism epidemic may have occurred in the Indian subcontinent around 1500 BC. According to Chopra, "In the old Hindu literature, the

\footnotetext{
From the Departments of Neurology/Neurosurgery \& Pediatrics, McGill University; Division of Pediatric Neurology, Montreal Children's Hospital-McGill University Health Center, Montreal, Quebec, Canada.

Received April 8, 2011. Final Revisions Submitted May 16, 2011.

Correspondence to: Michael Shevell, Room A-514, Montreal Children's Hospital, 2300 Tupper, Montreal, Quebec, H3H 1P3, Canada.
} 
Bhavaprakasa, it is written that the triputa pulse causes a man to become lame and crippled and it irritates the nerves" 5 . The first written record of a lathyrism epidemic in the Western world appeared around $300 \mathrm{BC}$ and was ascribed to Hippocrates. He described a famine in the town of Ainos in his book Epidemics: "those who eat constantly of beans, both male and female, were affected with weakness in their legs, from which they escaped with difficulty" 6 . Pedanius Dioscorides, in the first century AD, cautioned against eating the dangerous peas and his Roman contemporary, Pliny the Elder, echoed his warning ${ }^{4}$. The propensity of the grass pea to paralyze the lower extremities was appreciated throughout Europe during the Middle Ages, when the disease apparently reached alarming proportions. In 1671, Duke Georg of Württemberg issued the first ever edict banning the consumption of Lathyrus peas due to its "paralyzing effects on the legs"?.

Lathyrus peas were known to be resistant to drought and disease. Knowledge of their noxious nature was usually widespread amongst the rural people in the regions where it grew $^{8}$. Requiring minimal tending, Lathyrus can be grown with little effort and is nutritionally valuable because of its high protein content. Even though they were aware of its dangers, populations have been forced to resort to this crop during extended drought and during times of famine and war, the alternative being starvation. Based on the historical literature, it has been estimated that consumption of the pea as one-third to one-half of the diet for two or three months is sufficient to induce neurological sequelae ${ }^{9}$. Sir William Henry Sleeman, an administrator in 19th century India, recounted that after three years of drought and blight, the local population succumbed to eating the wild-growing grass pea that had been normally fed to cattle. Eventually, about half of the population "began to be deprived of the use of their limbs below the waist" and "no person once attacked has been found to recover" 10 .

The name lathyrism was first applied to the clinical disease by Arnaldo Cantani in $1873^{11}$. Montreal endocrinologist Hans Selye coined the terms neurolathyrism and osteolathyrism in his review of the literature in 1957 in order to differentiate between the two conditions ${ }^{12}$. Each disease seemed to have been induced by distinct lathyrogens from different Lathyrus species and the latter was at the time only found in experimental models. More specifically, although there exists overlap, osteolathyrogens are principally found in L. odoratus, L. hirsutis, and L. pusillus whereas neurolathyrogens are principally present in such Lathyrus species as sativus, cicera, clymenum, latifolius, sylvestris Wagner, and sphaericus and also in Vicia sativa and Ervum ervilia ${ }^{4}$.

The component of L. sativus responsible for corticospinal motor neuron degeneration was identified as early as $1963^{13,14}$. It is currently known as $\beta$-N-oxalyl-L- $\alpha, \beta$-diaminopropionic acid $(\beta$-ODAP), but was previously known as $\beta$-N-oxalylamino-Lalanine $(\mathrm{BOAA})^{15,16}$. Its effects are that of a glutamate (i.e. excitotoxin) analog, hyperactivating non-N-methyl-D-aspartic acid (NMDA) receptors (2-amino-3-(5-methyl-3-oxo-1,20xazol-4-yl) propanoic acid (AMPA) and kainate receptors) ${ }^{17,18}$. The neuro-excitotoxin over-stimulates the non-NMDA glutamate receptors, leading to increased calcium influx and ultimately causing neuronal degeneration ${ }^{14,19}$. In addition to perturbations in calcium homeostasis, $\beta$-ODAP has also been shown to increase the production of reactive oxygen species and impair mitochondrial function as evidenced by loss of complex I activity in vitro ${ }^{19,20}$. The few post-mortem neuropathological studies have shown variable degrees of degeneration of both the cortical and spinal upper motor neurons in human neurolathyrism ${ }^{4,14}$.

With regards to osteolathyrism, one implicated plant component appears to be $\beta$-aminopropionitrile ( $\beta \mathrm{APN})$. It leads to increased connective tissue fragility, resulting in a failure of developing connective tissue fibres to properly cross-link. Direct binding of the agent to lysyl oxidase, the enzyme needed for proper connective tissue cross-linking, may mediate this process $^{12,21}$.

\section{Vapniarka and Transnistria}

Following the Nazi invasion of the Soviet Union in 1941 during Operation Barbarossa, the Red Army employed a scorched earth policy during their forced retreat. Into this territory, the Romanian government (allied with the Axis powers) deported Jews from the provinces of Bukovina and Bessarabia to what was then referred to as Transnistria, the territory between the Dniester and Bug rivers that is currently split between Ukraine and Moldavia. West of Transnistria is Bessarabia, which is bound by the Prut and Dniester rivers and currently split between Moldavia and Ukraine. Bukovina lies to the west of northern Bessarabia, and is currently split between Romania and Ukraine (see Figure). Hitler placed Transnistria under Romania's exclusive control as a reward for its contribution to the Nazi war effort. Up to 140,000 Jews were forced to make the trek across the Dniester to Transnistrian ghettos and concentration camps, mostly during the fall and winter of 1941. The deportees were obliged to fend for themselves under terrible conditions and most were subjected to the gradual process of extermination through famine and disease ${ }^{22}$. Romania not only participated in the genocide of the Jews, but also independently implemented its own autonomous genocidal policies ${ }^{23,24}$.

In Vapniarka, Transnistria, a detention camp was established in the early autumn of 1941. It was built on the grounds of a former Soviet cavalry training base. Approximately 1200 detainees were originally imprisoned there. During the camp's first winter, a large number perished from either starvation, hypothermia, or an epidemic of typhus. In the summer of 1942, the surviving prisoners were marched out of the camp, shot by the Romanian guards ${ }^{25,26}$ and their bodies dumped into local anti-tank ditches ${ }^{27}$. Not long afterwards, the camp was again utilized to imprison "political prisoners" who were accused of Communist, Socialist, or Zionist activities or sympathies. In August 1942, Lieutenant Colonel Ion C. Murgescu was appointed the camp's commander. Approximately 1200 men, women, and children, of whom over $90 \%$ were Jews, arrived at Vapniarka during late September $1942^{27}$.

Among them was Dr. Arthur Kessler. He received his medical degree from the University of Vienna Faculty of Medicine in 1929. After spending a year as a physician in the Romanian army, he spent three years in a German hospital near Zwickau. In 1933, he left Germany for Czernowitz (Cernauti in Romanian), a city in Bukovina, due to increasing anti-Semitism in the Third 


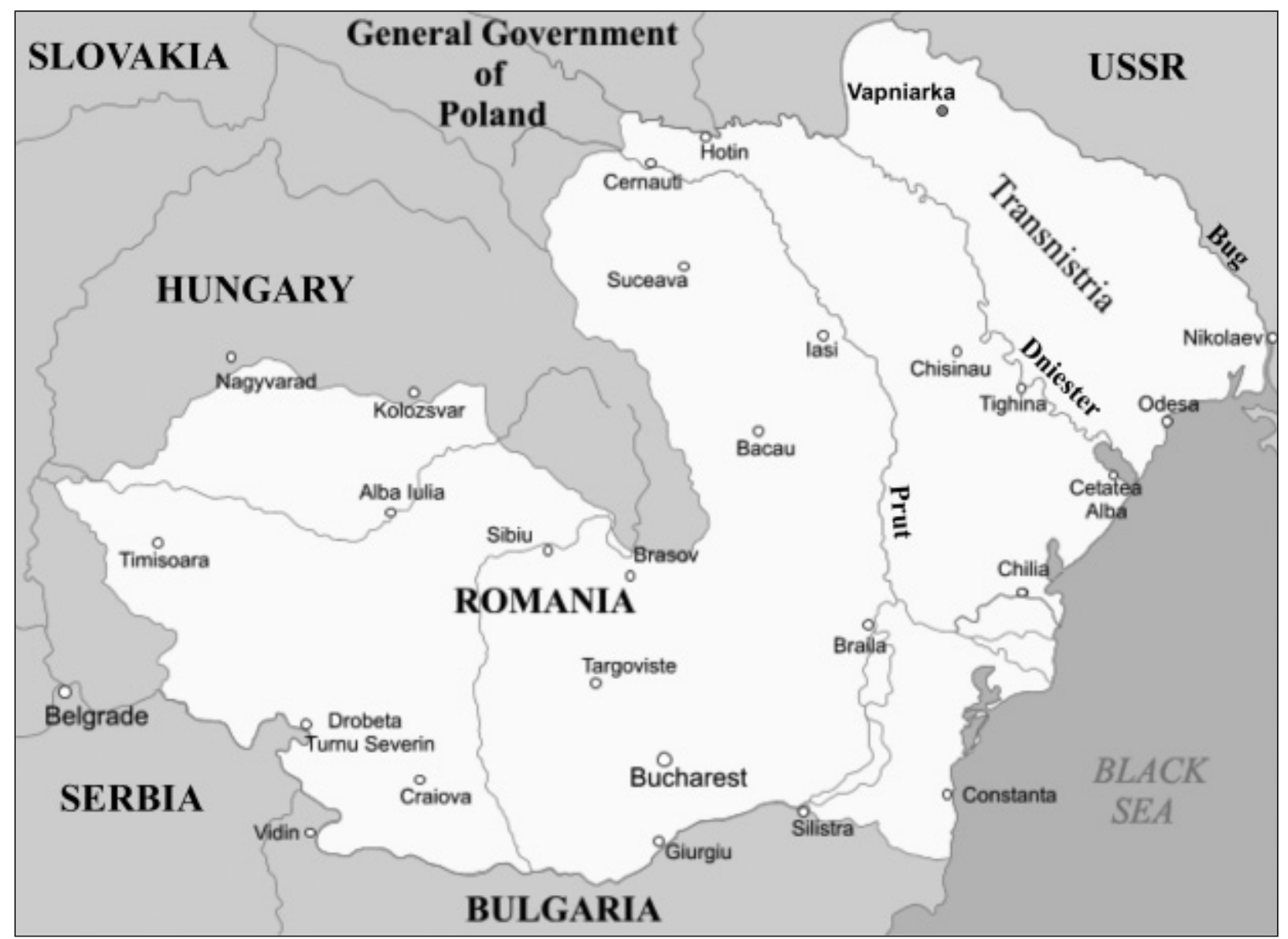

Figure: Map of Romania during World War II (1941-1944).

Reich $^{28}$. That year corresponded to the introduction in Germany of the Civil Service Law, the predecessor of the Nuremberg Race Laws of 1935. These laws excluded Jews from appointments in the Civil Service, and, concurrent with an environment in which they were openly regarded as the enemy, limited their opportunities in medicine ${ }^{29}$. On June 28, 1940, the Romanian government evacuated Northern Bukovina and Bessarabia as the Red Army prepared to invade these territories. The local Jews were officially later accused of supporting the invasion and betraying their Romanian compatriots ${ }^{30}$. Many of Kessler's Romanian colleagues fled Czernowitz and he consequently assumed the position of hospital manager. Romanian rule was reestablished after Operation Barbarossa in June 1941 and Kessler was accused of being an agent of the Soviet Union and consequently jailed. He was released in early 1942, only to be rearrested and imprisoned in Camp Vapniarka in September $1942^{28}$

Lieutenant Colonel Murgescu greeted the initial group of camp inmates with the rules of the camp. He finished with these words: "You have come here on two legs. You will leave here on all fours!" 31 Murgescu's prediction would unfortunately prove eerily prophetic.

\section{Neurolathyrism in Vapniarka}

Gheorghe Alexianu, the governor of Transnistria, complained that he was experiencing difficulty supplying the concentration camps in his jurisdiction with adequate food ${ }^{27}$. Alexianu was a member of the Council of Ministers, and directly answerable to Marshal Ion Antonescu, Leader and Prime Minister of Romania during most of World War $\mathrm{II}^{22}$. In response to his complaint, the Romanian command at Vapniarka, which was one of several concentration camps in Transnistria, decided to feed the inmates grass pea fodder, L. sativus. The government of Transnistria had at its disposal a large quantity of pea fodder since the withdrawing Soviet cavalry base had left it behind. The Soviets had occasionally used it as a horsefeed supplement in a blend with other grains, but never alone because of the known toxicity $^{26}$. The grass pea was widely known by the local peasantry to be toxic to humans, and presumably by the Romanian authorities as well because it was not fed to them ${ }^{27,32}$. According to Kessler, beginning on September 16, 1942, the prisoners' daily ration consisted of $200 \mathrm{~g}$ of bread baked of barley and chopped straw and $400 \mathrm{~g}$ of L. sativus cooked in salt water $^{33,34}$.

Approximately three months later, at the end of December 1942 , some of the prisoners began displaying symptoms of an 
unknown illness. The Ukrainian prisoners, who had arrived at the camp a month or so before the Jews, were the first to show the symptoms. There were over 20 doctors amongst the inmates who took care of the afflicted in the makeshift infirmary and attempted to diagnose the disease ${ }^{32}$. According to Kessler's memoir, one day, a Dr. Moritz came to him and said, "Listen, I have an old guy among my Ukrainians who walks funny. Come and look at him." After examining the patient, Kessler noted, "The man's knee and foot reflexes jump when tapped, as do his toes when I stroke the soles of his feet." He diagnosed a spastic paralysis of the legs and advised Moritz to "treat it as syphilis and to start with iodine and bismuth." But the patient did not recover, and soon more Ukrainians developed an abnormal gait, and as Kessler noted, "when I tap their Achilles tendon the whole leg jumps and continues to jerk." He remarked that the mysterious disease did not spread through contagion since "we have not heard of a single case among the guards." What distinguished the inmates from the camp staff was their diet. The Ukrainians had been eating the peas for the longest period of time. The doctors examined the peas for additives and for ergot, but failed to find anything suspicious ${ }^{33}$. Kessler therefore concluded that the grass pea itself was the source of the epidemic. He observed, "We are eating poison and we will die of it" ${ }^{\prime 3}$. The acute clinical picture, as accurately described by Kessler in the Hebrew and German reports in 1946 and 1947 respectively, often presented with severe recurrent painful muscle cramps of several minutes duration in the lower extremities. It also tended to lead to abnormal gait ${ }^{34,35}$. It also tended to lead to abnormal gait and progressive spastic paraparesis of the lower extremities. ${ }^{34,35}$ Painful pollakiuria and incontinence commonly followed. By late January 1943, about 110 inmates experienced severe paralysis ${ }^{27,33,36}$. The upper extremities and cranial nerves were less often involved. Peripheral paresthesias were likewise rare.

Alongside other inmate camp leaders, Kessler appealed to the camp commanders to change their diet and provide medical supplies; however, they were ignored. According to Kessler's memoir, one of the camp commanders responded to the delegation of inmates who pleaded with him, "What makes you think that we are interested in keeping you alive?"33. Some of the inmates began an intense educational campaign to alert prisoners to the dangers of the grass pea. They were advised to refuse their daily rations and embark on what Kessler described as "not a hunger strike, but the highest degree of abstinence." At the same time, those who worked outside the camp brought back and shared some of the food they were able to obtain at their external workplace. The wealthier inmates within the camp shared the food they bought at the canteen, which was occasionally permitted to operate. The "strike" culminated when the inmates blocked the entry of grass peas at the camp gate. Lieutenant Colonel Murgescu realized that behind the scenes a wellorganized resistance was building. Although they were determined to uncover the organizers, inmate solidarity ensured that the camp administrators did not succeed $25,27,33$.

A Romanian government doctor visited the camp in early 1943 to check for safeguards against the recurrence of a typhus outbreak. This visit was followed by several others, including one by Governor Alexianu, who met with a number of his childhood friends who were imprisoned there. He ultimately promised to send a commission to examine the situation in the camp ${ }^{25,26,31}$. Although there was no official recognition or acknowledgement that the pea fodder had any relevant connection to the epidemic, on January 23, 1943, the toxic pea was eliminated from the prisoners' diet. According to a report dated February 29, 1943, 611 detainees ultimately displayed symptoms of neurolathyrism ${ }^{37}$. Kessler estimated that 800 inmates displayed the symptoms ${ }^{33}$. It is impossible to estimate the number of lathyrism deaths due to the manifold adverse and potentially fatal factors that existed in the camp. Kessler claimed that several inmates died of lathyrism directly due to a vasomotor variant of the disease with severe necrosis of the toes and feet and subsequent gangrene ${ }^{34}$. Soon after the war, vasomotor symptoms and gangrene were described in three survivors $^{38}$.

In retrospect, the decision to feed the toxic pea to the Vapniarka inmates was made for both practical and more heinous reasons. The pea represented a cheap and available source of food. However, since it was withheld from the camp command, it would be fair to say that it was known to be toxic for humans and thus did conform to the Romanian version of the exterminationist Final Solution ${ }^{22}$.

\section{After Vapniarka}

There was awareness of the neurolathyrism epidemic in Romania and the parents of one of the authors (FA) had heard about it from Dr. Anghel Radovici, a brilliant neurologist in Bucharest who was the first to describe photogenic self-induced seizures in $1932^{39}$. Radovici was part of the Commission for the Assistance of Transnistria Deportees and was made aware of the Camp Vapniarka epidemic in January 1943. This commission helped identify the pea as the source of paralysis and conveyed their findings to the Minister of Public Health, but to no avail. Radovici described the Vapniarka epidemic in $1945^{40}$. Thousands of orphans survived the Transnistria killing fields. An author's (FA) mother, Anny Andermann, with Grete Bibring and Betty Schwefelberg, launched a successful campaign to save and repatriate these orphans.

In early 1943, with the tide of World War II turning against the Axis and their defeat at Stalingrad imminent, the Romanian Ministry of the Interior established a committee to repatriate those Jews sent to Camp Vapniarka for "unjustifiable" reasons while those sent as Communists were exempted. On March 16, the committee recommended the release of 554 inmates because they had been imprisoned on "vaguely articulated suspicions" 22,30. On May 1, Alexianu ordered the release of 427 Jews, amongst them Kessler, but mandated that they be moved to specific ghettos in Transnistria as they were forbidden to return to Bessarabia and Bukovina ${ }^{22,37}$. Many Jews, including Kessler, escaped Transnistria in 1944 ahead of the advancing Red Army $^{28}$. Less than half of the roughly 140,000 Jews who were deported to Transnistria survived as of September 1, 1944 ${ }^{22,37}$. Many of those who survived Vapniarka are still facing the consequences of the disease today ${ }^{41}$. Both Alexianu and Antonescu were tried as war criminals and executed by firing squad on June $1,1946^{22}$.

Soon after escaping Transnistria in 1944, Kessler immigrated to what was then Palestine with his wife and daughter ${ }^{28}$. Approximately 300 of the Camp Vapniarka survivors did 
likewise. After the war, he described neurolathyrism as it occurred in Vapniarka in meticulous detail in both Hebrew and $\operatorname{German}^{34,35}$. He also wrote a memoir, which was recently translated into English ${ }^{33}$. His reports represent a remarkable description of the etiology and acute sequelae of neurolathyrism. He followed many of the prisoners who settled in Israel after the war and suffered from this condition, but practised primarily as an allergist. He was diagnosed with Alzheimer's disease in Tel Aviv in the early 1990s and died on August 18, 2000 at 76 years of age a $^{28}$.

Colleagues of Kessler in Israel, neurologists Dan Cohn and Max Streifler, serially examined 200 patients who had contracted neurolathyrism in Vapniarka over a 30 -year period. This evaluation of patients with chronic neurolathyrism at the time constituted the longest ever follow-up. Their reports, published in the early 1980 s, have greatly contributed to our knowledge regarding the chronic effects of the disorder ${ }^{42,43}$. All of the patients examined had a spastic paraparesis with a gait disturbance. The more severely affected tended to walk on the balls of their feet with a stiff-legged, lurching, scissoring gait and often required one or two canes or crutches for support. Some could not walk and relied on a wheelchair ${ }^{42}$. This typical gait was due to greatly increased tone in the thigh extensors and adductors and in the gastrocnemius muscles ${ }^{44}$. Four patients showed mild involvement of the upper limbs with mild spasticity and bilateral Hoffman's signs. None of the patients had cranial nerve involvement. Neurogenic bladder symptoms were less prominent in the chronic stage than in the acute phase.

Cohn and Streifler were the first to describe lower motor neuron involvement, albeit in only 14 of the 200 patients $^{42}$. The lower motor neuron deficit manifested as marked atrophy of the flexors and extensors of the feet that was not commensurate with disuse. Marked atrophy has also been found in a minority of Indian and Bangladeshi neurolathyrism patients in a separate study ${ }^{44}$. To lend credence to the involvement of peripheral motor nerves, an electromyographic study on 11 Vapniarka patients was performed by Cohn. It showed abnormalities in both proximal and distal lower limb muscles in two patients ${ }^{45}$. These results, however, are not disease-specific and may be attributable to transsynaptic degeneration, polyradiculopathy, or normal aging. Moreover, another study on Indian patients found only mild subclinical (ie, electrophysiologic) peripheral motor neuropathy ${ }^{46}$. As such, the clinical significance of lower motor neurons involvement seems to be marginal.

Twelve patients had sensory neuropathy in the lower extremities $^{42}$. They showed delayed sensory nerve conduction only in the lower extremities. Electron microscopy of thin sections of sural nerve biopsies showed myelin overgrowth consistent with a tomaculous neuropathy ${ }^{43}$. Sensory changes were also described in a cohort of Greek patients who contracted neurolathyrism due to a severely limited food supply in the winter of 1941-1942, when Greece was occupied by the Axis powers ${ }^{47}$.

Cohn and Streifler were the first to demonstrate the existence of an ossification abnormality consistent with osteolathyrism, which had only been described in experimental models of lathyrism. Five of the 45 patients evaluated roentgenographically showed absence of fusion of several epiphyses and bowing of the femur, features typical of osteolathyrism ${ }^{43,48}$. At the age when these patients were exposed to L. sativus, the secondary centres of ossification of the iliac and ischial bones and vertebral bodies may not have been fully fused and ossified. Other skeletal changes, such as spondylolisthesis and vertebral compression fractures, were ascribed to the strains occasioned by the spastic paraparetic lower limbs. The strain-related skeletal changes, but not the ossification abnormalities, were also described in the cohort of Greek patients ${ }^{47}$.

In 1976, Cohn and Streifler, along with neuropathologist Asao Hirano, added to the scant central neuropathologic knowledge by performing a morphological and ultrastructural study of the nervous system of a Vapniarka inmate who developed neurolathyrism at the age of 35 and died of hematopericardium at the age of $67^{49,50}$. The thoracic and lumbar spinal cord showed bilateral atrophy of the pyramidal tracts due to loss of axons and myelin. The fasciculus gracilis (tract of Goll) demonstrated degeneration as well. The anterior horn cells showed swelling, lateral displacement of the nucleus, and loss of Nissl substance. In addition, they observed previously undescribed rodlike eosinophilic inclusions resembling Hirano bodies in the anterior horn cells, possibly accounting for the subclinical and uncommon lower motor neuron manifestations ${ }^{43}$. Cognitive evaluation of the Vapniarka inmates did not show a cognitive decline ${ }^{51}$.

A number of human experimentation atrocities were carried out in the concentration camps of the Third Reich. These experiments included efforts to study the human response to inhumane exposures such as high altitudes, mustard gas, and freezing temperatures ${ }^{52}$. Although not part of a purposefully designed campaign carried out by unscrupulous Nazi physicians, the inmates of Vapniarka too were subjected to inhumane conditions. Their cruel experience later lent itself to legitimate scientific study.

Kessler saved his fellow inmates from permanent paralysis and ultimate death. Had it not been for his astute diagnosis and the inmates' organized resistance to contain the disease, neurolathyrism may have been remembered as another weapon in the Nazi's genocidal campaign, rather than as a symbol of individual and collective resilience and triumph in the face of unimaginable horror. Finally, quoting the late Radovici on Kessler, to whom he dedicated his address on lathyrism: "An example of heroic resistance against the Teutonic fury unleashed against an innocent and unarmed population... In the midst of horrible circumstances, in the 'house of the dead,' he conserved the tranquility of the soul and the purity of the spirit to scientifically trace the evolution of the epidemic of paraplegic lathyrism" $"$.

\section{ACKNOWLEDGMENTS}

The authors thank Alba Rinaldi for secretarial assistance. We also thank the MCH Foundation for salary support for MIS during the preparation of this manuscript.

\section{REFERERNCES}

1. Peiffer J. Assessing neuropathological research carried out on victims of the 'euthanasia' programme. Med Hist J. 1999;34: 339-56.

2. Shevell M. Neurosciences in the Third Reich: from Ivory Tower to death camps. Can J Neurol Sci. 1999;26:132-8. 
3. Alexander L. Medical science under dictatorship. N Engl J Med. 1949;221:39-47.

4. Bruyn GW, Poser CM. The history of tropical neurology: nutritional disorders. Canton, MA: Science History Publications/USA; 2003. p. 89-108.

5. Chopra R. Lathyrism. In: The British encyclopaedia of medical practice. London: Butterworth; 1935. Vol 7,p. 651-7.

6. Hippocrates. The history of epidemics. In seven books. Book 2, Section IV. Translated into English from the Greek by S. Farr. London: T. Cadell, In the Strand; 2003. p. 59-60.

7. Schuchardt B. Zur geschichte und casuistik des lathyrismus. Dtsch Arch Klin Med. 1887;40:312-46.

8. Cohn DF, Streifler M. Neurolathyrism: historical notes. Koroth. 1978;7:147-52

9. Barrow MV, Simpson CF, Miller EJ. Lathyrism: a review. Quart Rev Biol. 1974;49:101-28.

10. Sleeman WH. Rambles and recollections of an Indian Official. London: J. Hatchard and Son; 1844

11. Cantani A. Latirismo. Il Morgagni. 1873;15:754-65.

12. Selye H. Lathyrism. Rev Canad Biol. 1957;16:1-83.

13. Adiga P, Rao S, Parma P. Some structural features and neurotoxic action of a compound from L. sativus seeds. Curr Sci. 1963;32: 153-4

14. Spencer PS. Food toxins, AMPA receptors, and motor neuron diseases. Drug Metab Rev. 1999;31:561-87.

15. Nunn PB, Seelig M, Zagoren JC, Spencer PS. Stereospecific acute neuronotoxicity of "uncommon" plant amino acids linked to human motor-system diseases. Brain Res. 1987;410:375-9.

16. Bridges R, Hatalski C, Shim S, et al. Gliotoxic properties of the lathyrus exotoxin ( $\beta$-L-ODAP). Brain Res. 1991;561:262-8.

17. MacDonald JF, Morris ME. Lathyrus excitotoxin: mechanism of neuronal excitation by L-2-oxalylamino-3-amino-and L-3oxalylamino-2-amino-propionic acid. Exp Brain Res. 1984;57: 158-66.

18. Olney J. Excitotoxins in food. Neurotoxicology. 1994;15:535-44.

19. Van Moorhem M, Lambein F, Leybaert L. Unraveling the mechanism of $\beta$-N-oxalyl- $\alpha, \beta$-diaminopropionic acid ( $\beta$-ODAP) induced excitotoxicity and oxidative stress, relevance for neurolathyrism prevention. Food Chem Toxicol. 2011;49: 550-5.

20. Sriram K, Shankar SK, Boyd MR, Ravindranath V. Thiol oxidation and loss of mitochondrial complex I precede excitatory amino acid-mediated neurodegeneration. J Neurosci. 1998;18: 10287-96.

21. Dawson DA, Rinaldi AC, Pöch G. Biochemical and toxicological evaluation of agent-cofactor reactivity as a mechanism of action for osteolathyrism. Toxicology. 2002;177:267-84.

22. Ioanid R. The Holocaust in Romania. Chicago: Ivan R Dee; 2000.

23. Ancel J. Transnistria, 1941-1942: the Romanian mass murder campaigns. Tel Aviv: Goldstein-Goren Diaspora Research Center, Tel Aviv University; 2003.

24. Dumitru D. The use and abuse of the Holocaust: historiography and politics in Moldova. Holocaust Genocide Studies. 2008;22: 4973.

25. Gall M. Finsternis: durch gefängnisse, KZ Wapniarka, massaker und kommunismus. Ein lebenslauf in Rumänien, 1920-1990. Constance: Hartung-Gorre Verlag; 1999.

26. Simon N. “... auf allen vieren werdet ihr hinauskriechen!”: Ein zeugenbericht aus dem KZ Wapniarka. Berlin: Institut Kirche und Judentum; 1994.

27. Benditer I. Cattle fodder for the victims. In: Carmelly F, editor. Shattered! 50 Years of Silence. Toronto: Abbeyfield Publishers; 1997. p. 181-202.

28. Kessler D. Dr. Arthur Kessler (1903-2000). Lathyrus Lathyrism Newsletter. 2003;3:2-4
29. Proctor RN. Anti-Semitism in the German medical community. In: Racial hygiene-medicine under the Nazis. Cambridge, MA: Harvard University Press; 1988: p. 131-76.

30. Ancel J. Documents concerning the fate of Romanian Jewry during the Holocaust. New York: Beate Klarsfeld Foundation; 1986.

31. Shachan A. Burning ice: the ghettos of Transnistria. New York: Columbia University Press; 1995.

32. Hirsch M, Spitzer L. Testimonial objects: memory, gender and transmission. Poetics Today. 2006;27:355-86.

33. Hirsch M, Spitzer L. “There was never a camp here!” In: Ghosts of home: the afterlife of Czernowitz in Jewish memory. Berkeley and Los Angeles, CA: University of California; 2010. p. $197-231$

34. Kessler A. Lathyrismus. Monatschr Psychiatr u Neurol. 1947;113: 345-76.

35. Kessler A. Lathyrism in man. Harefuah. 1946;31:111-4.

36. Hilberg R. The destruction of the European Jews, 3rd ed. New York: Yale University Press; 2003.

37. Carp M. Cartea Neagra: Le livre noir de la destruction des juifs de Roumanie, 1940-1944. Translated, annotated and edited by Laignel-Lavastine A. Paris: Éditions Denoël; 2009.

38. Ortner E. Ueber Lathyrismus. Wien Klin Wochenschr. 1948;60: 291-3.

39. Radovici A, Misirliou V, Gluckman M. Épilepsie reflexe provoquée par excitations optiques des rayons solaires. Rev Neurol. 1932;1: $1305-8$.

40. Radovici A. Sur une epidemie de lathyrisme. Bull Acad Med Roum. 1945; 10:77-86

41. Sigler E, Shvidel L, Shtalrid M, Berrebi A. Lathyrism, leg cramps, and thrombocytopenia: cascade of events starting in a concentration camp. Am J Med. 2007;120:e3.

42. Cohn DF, Streifler M. Human neurolathyrism. A follow up study of 200 patients. Part I: clinical investigation. Schw Arch Neurol Psych. 1981;128:151-6.

43. Cohn DF, Streifler M. Human neurolathyrism. A follow up study of 200 patients. Part II: special investigations. Schw Arch Neurol Psych. 1981;128:157-63.

44. Ludolph AC, Hugon J, Dwived MP, Schaumburg HH, Spencer PS. Studies on the aetiology and pathogenesis of motor neuron diseases. 1. Lathyrism: clinical findings in established cases. Brain. 1987;110:149-65.

45. Drory VE, Rabey MJ, Cohn DF. Electrophysiologic features in patients with chronic neurolathyrism. Acta Neurol Scand. 1992; 85:401-3

46. Misra UK, Sharma VP. Peripheral and central conduction studies in neurolathyrism. J Neurol Neurosurg Psychiatry. 1994;57:572-7.

47. Paissios CS, Demopoulos T. Human lathyrism. Clin Orthop. 1962; 23:236-49.

48. Weintroub S, Cohen DF, Salama R, Streifler M, Weissman SL. Skeletal findings in human neurolathyrism. Is there a human osteolathyrism? Eur Neurol. 1980;19:121-7.

49. Hirano A, Llena J, Streifler M, Cohn D. Anterior horn cell changes in a case of neurolathyrism. Acta Neuropathol. 1976;35:277-83.

50. Streifler M, Cohn D, Hirano A, Schujman E. The central nervous system in a case of neurolathyrism. Neurology. 1977;27:1176-8.

51. Paleacu D, Cohn DF, Rabey JM. Cognitive evaluation of patients with chronic neurolathyrism. Parkinsonism Relat Disord. 1999; 51:55-8.

52. Trials of war criminals before the Nuremberg military tribunals under control council law 10. Washington, DC: US Government Printing Office; 1950.

53. Radovici A. Une épidémie de lathyrisme pendant la guerre. Société Médicale des Hôpitaux de Bucarest. 1945;Nr. 5-7:1-48. 